\title{
A here cysticus elváltozásai csecsemőkorban - négy eset ismertetése
}

\author{
Balogh Dorottya dr. ${ }^{1}$ - Biró Ede dr. ${ }^{1}$ - Garai Gábor dr. ${ }^{2}$ \\ Mohay Gabriella dr. ${ }^{3}$. Semjén Dávid dr. ${ }^{4}$. Vástyán Attila dr. ${ }^{1}$
}

${ }^{1}$ Pécsi Tudományegyetem, Általános Orvostudományi Kar, Klinikai Központ, Gyermekgyógyászati Klinika, Manuális Tanszék, Pécs

${ }^{2}$ Heim Pál Országos Gyermekgyógyászati Intézet, I. Gyermek Sebészeti és Traumatológiai Osztály, Budapest ${ }^{3}$ Pécsi Tudományegyetem, Általános Orvostudományi Kar, Klinikai Központ, Orvosi Képalkotó Klinika, Pécs ${ }^{4}$ Pécsi Tudományegyetem, Általános Orvostudományi Kar, Klinikai Központ, Pathologiai Intézet, Pécs

Csecsemókorban a here cysticus elváltozásai ritka entitásnak számítanak. Az angol nyelvű szakirodalom kevés hasonló esetről számol be, a 2000-es évek elejéig publikált esetek harmadában orchiectomia történt. A hisztológia a leggyakrabban teratomát, a legritkábban egyszerú cystát igazol. Mindkét elváltozás jóindulatú, egyéves kor alatt a leggyakoribb. Közleményünkkel arra szeretnénk felhívni a figyelmet, hogy ezen esetek kezelése során törekedni kell a here megtartására. A Pécsi Tudományegyetem Klinikai Központ Gyermekgyógyászati Klinikájának Manuális Tanszékén és a Heim Pál Országos Gyermekgyógyászati Intézet I. Gyermek Ssebészeti és Traumatológiai Osztályán 2015 és 2018 között 4 csecsemőben észleltük a here cysticus elváltozását. A betegek kórtörténeti adatainak részletes retrospektív elemzését és a szakirodalom áttekintését végeztük. Mind a 4 alkalommal a csecsemő féléves kora előtt észleltek egyoldali, panaszokat nem okozó herezacskófél-megnagyobbodást. Az ultrahangvizsgálat 3 esetben szoliter cysticus képletet talált. 1 esetben szeptált, sűrű folyadékkal telt cysticus képletet véleményezett, számottevő hereállomány nem mutatkozott. Ennél a betegnél mágnesesrezonancia-vizsgálat is készült, mely teratoma lehetőségét vetette fel. A feltárás során mindegyik csecsemőben cysticus képletet találtunk. 3 betegnél hereszövet-megtartó mútétet (enucleatiót) végeztünk. l esetben az érdemben megtartható hereszövet hiánya, valamint teratoma gyanúja miatt orchiectomia történt. A kórszövettan két esetben egyszerú cystát, két esetben praepubertalis teratomát igazolt, melyek jóindulatú elváltozások. A here cysticus elváltozásai csecsemőkorban döntő többségben benignusak. Az egyszerű cysta és a praepubertalis teratoma egyaránt jóindulatú elváltozás, malignus transzformációra nem hajlamosak. A képalkotó eljárások közül az ultrahangvizsgálat elegendő lehet a kezelési terv felállításához. Mindig törekedni kell a here megtartására, a lehető legtöbb hereszövet megkímélésére. Kórszövettani vizsgálat nélkül a here eltávolítása ebben az életkorban nem javasolt.

Orv Hetil. 2020; 161(48): 2043-2048.

Kulcsszavak: here, cysta, teratoma, csecsemő, heremegtartó kezelés

\section{Cystic lesions of the testis in infancy - case series of four patients}

Cystic lesions of the testis are rare in infancy. Few similar case-series were published in the English literature. Orchiectomy was reported in one-third of the cases until the early 2000s. Histology mostly confirms teratomas, rarely simple cysts. Both are benign and most common under the age of one year. Our aim is to draw attention to the importance of testicular sparing surgery (enucleatio), whenever possible. At the Medical Centre of the Department of Pediatrics of the Division of Paediatric Surgery, Pécs and at the Department of Pediatric Surgery and Traumatology of the Heim Pal Children's Hospital, Budapest, four cystic testicular lesions were treated in infancy between 2015 and 2018. We performed retrospective analysis and reviewed relevant literature. Our patients were under six months and an unilateral, painless scrotal enlargement appeared. Ultrasound described cystic lesion in the testis in three cases. In one case a septated, echogenic, liquid-filled cystic lesion was detected, with no significant amount of testicular tissue. Magnetic resonance imaging scan of this patient predicted the diagnosis of teratoma. During the surgeries, cystic lesions were found in all cases. Enucleatio was performed in three patients. Orchiectomy was carried out once due to the suspicion of teratoma and the lack of salvageable testicular tissue. Histopathology confirmed simple cysts in two babies and prepubertal teratomas in the others. Testicular cystic lesions are predominantly benign in infancy. Simple cysts and prepubertal teratomas are benign, not prone to malignant transformation. Ultrasound is reliable for preoperative planning. Testicular tissue sparing surgery must be considered and without histopathology orchiectomy should not be performed. 
Keywords: testis, cystic lesion, teratoma, infant, testicular sparing surgery

Balogh D, Biró E, Garai G, Mohay G, Semjén D, Vástyán A. [Cystic lesions of the testis in infancy - case series of four patients]. Orv Hetil. 2020; 161(48): 2043-2048.

(Beérkezett: 2020. június 9.; elfogadva: 2020. július 4.)

\section{Rövidítések}

AFP = alfa-fetoprotein; béta-hCG = a humán choriogonadotropin béta-alegysége; $\mathrm{MR}=$ (magnetic resonance) mágneses rezonancia; PTE KK = Pécsi Tudományegyetem, Klinikai Központ; $\mathrm{UH}=$ ultrahang

Csecsemőkorban a here cysticus elváltozásai ritka entitásnak számítanak. Az angol nyelvú szakirodalom kevés hasonló esetról számol be, a 2000-es évek elejéig publikált esetek harmadában orchiectomia történt [1].

Gyermekkorban a here cysticus elváltozásai a legtöbb esetben jóindulatúak. A hisztológia a leggyakrabban teratomát, epidermalis cystát, a tunica albuginea cystáját és a legritkábban egyszerü herecystát igazol. Az egyszerü herecysta a scrotalis cysták között a legritkábban előforduló cysta, beleértve a mellékhere, a funiculus, a tunica vaginalis és a tunica albuginea cystáit [2]. A here tumoros elváltozásai közül praepubertalis korban a teratoma az egyik leggyakoribb elváltozás $[3,4]$.

Egyszerú herecystáról 1966-ban született először publikáció, abban a betegben teratoma gyanúja miatt orchiectomiát végeztek [5]. Csecsemőkorban a teratoma praepubertalis típusa van jelen, ez minden esetben benignus elváltozás [6].

A PTE KK Gyermekgyógyászati Klinikájának Manuális Tanszékén, illetve a Heim Pál Országos Gyermekgyógyászati Intézet I. Gyermek Sebészeti és Traumatológiai Osztályán 2015 és 2018 között 4 különböző, mégis hasonló esetet észleltünk, melyek diagnosztikájukban, terápiájukban részben eltérnek egymástól, így egy spektrumként is értékelhetők. Esetbemutatásaink célja a heremegtartó kezelés propagálása.

\section{Esetismertetések}

\section{Első beteg}

A csecsemő születésekor észlelték bal oldalon a herezacskófél megnagyobbodását, mely növekedést mutatott, de panaszokat nem okozott. A herezacskó ultrahang (UH)vizsgálata során egy $24 \times 16 \mathrm{~mm}$-es, tiszta bennékü, vékony falú cysticus képlet volt megfigyelhető a bal here állományában; a jobb oldalon kóros nem igazolódott. Az elváltozás méretére és helyzetére való tekintettel scrotalis feltárást követően enucleatiót végeztünk az ép hereszövet megkímélésével. A szövettani vizsgálat a testicularis teratoma praepubertalis típusát igazolta. A nyomon követés során 1,3 és 12 hónappal a mútét után történt kontrollUH-vizsgálat. Minden esetben normális nagyságú, homogén szerkezetú és jó vérellátású volt az operált here.

\section{Második beteg}

A csecsemő 5 hónapos korában észlelték bal oldalon a herezacskófél megnagyobbodását, amely növekedő tendenciát mutatott, de panaszokat nem okozott. UH-vizsgálat során elsőként $12 \times 8 \times 8$ mm-es, később $13 \times 10$ $\times 12$ mm-es cysticus képlet ábrázolódott a bal here felső harmadában; a jobb oldalon eltérés nem mutatkozott ( $1 / B$ ábra). Az elváltozás méretére és helyzetére való tekintettel scrotalis feltárást követően enucleatiót végeztünk, az ép hereszövet megkímélésével (2/A ábra). A kórszövettani vizsgálat aspecifikus herecystát véleményezett. A mütétet követő másfél éves nyomon követés alatt a fizikális vizsgálatok során mindkét herét megegyező nagyságúnak, normál tapintatúnak véleményezték.

\section{Harmadik beteg}

A csecsemő 4 hónapos korában észleltek a jobb oldalon herezacskófél-duzzanatot, amely panaszokat nem okozott. UH-vizsgálat során egy $25 \times 17 \times 20$ mm-es, szeptált, sưrû folyadékkal telt cysticus képlet mutatkozott, amely a jobb here teljes egészét elfoglalta; a bal oldalon ép viszonyok ábrázolódtak ( $1 / C$ ábra). A diagnózis további pontosítása céljából hasi-kismedencei kontrasztanyagos MR-vizsgálat készült, amely az elváltozást teratomának véleményezte $(1 / \mathrm{D}$ ábra). Onkoteam-megbeszélést követően, a képalkotó eljárásokra alapozva, inguinalis feltárást végeztünk. Mivel az intraoperatív lelet alapján érdemben megtartható hereszövetet nem találtunk, orchiectomiát (típusosan lágyéktáji feltárásból a here, a mellékhere, illetve a teljes funiculus eltávolítása) végeztünk. A kórszövettani vizsgálat benignus epithelialis cystát igazolt $(3 / A$ és $3 / B$ ábra). A nyomon követés során a bal oldali here kompenzatorikus növekedését észleljük, kisiskolás korban tervezzük a protetizálás első lépésének elvégzését.

\section{Negyedik beteg}

Hat hónapos csecsemőnél észleltek jobb oldali, panaszokat nem okozó herezacskófél-duzzanatot, amely a méretét nem változtatta. UH-vizsgálat során egy $13 \times 11 \mathrm{~mm}$-es, 


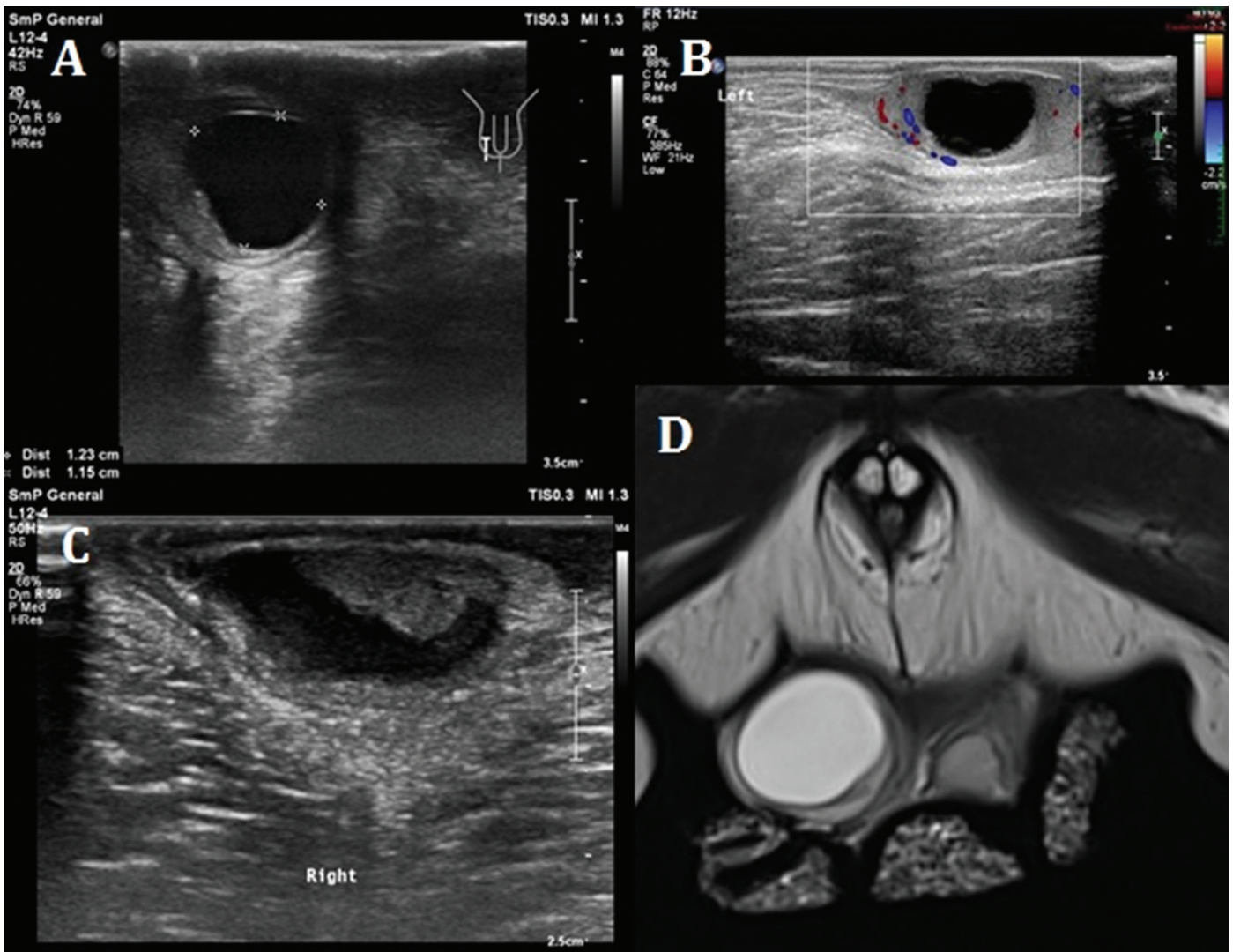

1. ábra
Képalkotó vizsgálatok
A) A 4. beteg ultrahangfelvétele adja a legreprezentatívabb képet arról, hogy az UH-vizsgálat során benignus, praepubertalis teratoma is ábrázolódhat egyszerú cystaként. B) A 2. beteg UH-vizsgálata során a Doppler-vizsgálat a cysticus elváltozás mellett keringést mutató hereszövet jelenlétét igazolja. C) A 3. betegünk UH-vizsgálata során sűrű bennékű szeptált képletet láttunk, mely felvetette a teratoma lehetőségét. D) A 3 . betegünknél végzett MR-vizsgálat teratomát véleményezett
$\mathrm{MR}=$ mágneses rezonancia; $\mathrm{UH}=$ ultrahang

a falában néhol meszesedést mutató cysticus képlet ábrázolódott a jobb here alsó pólusában; a bal oldalon kóros nem mutatkozott $(1 / A$ ábra). Scrotalis feltárást követően enucleatiót végeztünk az ép hereszövet megtartásával (2/B és 2/C ábra). Perioperatívan AFP- és béta-hCGszintet vizsgáltunk. Az AFP-szint minimális emelkedést mutatott, a béta-hCG a normáltartományban volt. A kórszövettani vizsgálat praepubertalis teratomát igazolt (3/C és $3 / D$ ábra). Tekintettel erre, a mütétet követő második és ötödik hónapban kontroll-UH- és -laborvizsgálatokat végeztünk. Az UH-vizsgálat mindkét alkalommal normál méretű és szerkezetû heréket írt le. A la-

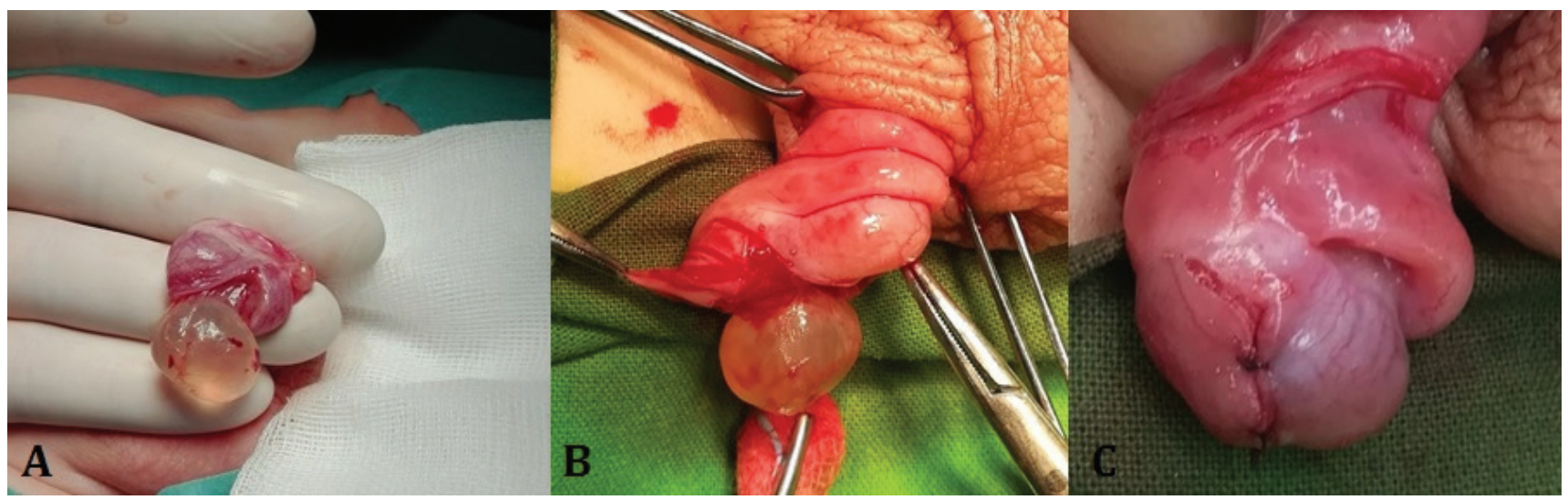

2. ábra Intraoperatív képek

A) A 2. betegünk intraoperatív makroszkópos képe a többihez hasonló volt, a kórszövettan aspecifikus herecystát írt le. B) A 4. betegünk intraoperatív makroszkópos képe. Jól látható a hasonlóság a 2/A ábrával összehasonlítva. Ebben az esetben jóindulatú teratoma volt a kórszövettani diagnózis. C) A 4. betegünkról készült intraoperatív felvétel az enucleatiót követóen 


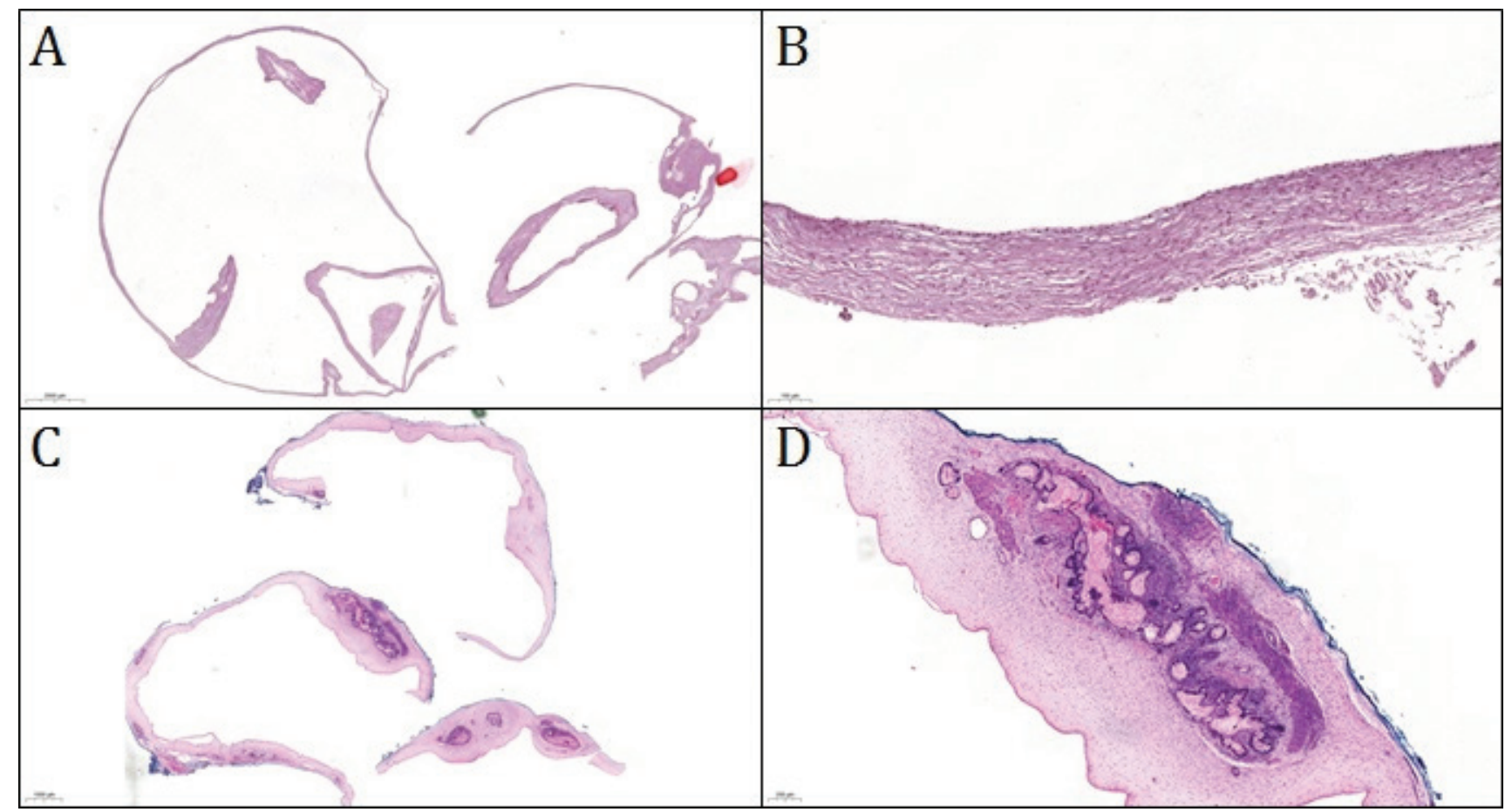

3. ábra

A) A 3. betegünk mikroszkópos képe, melynek alapján epithelialis cysta igazolódott: átmetszetben tágult cysticus területek mutatkoznak. B) A 3/A ábra felnagyítva: heges falú, köbhámmal bélelt tömlóborítás látható. C) A 4. betegünk mikroszkópos képe, melynek alapján praepubertalis teratoma igazolódott: átnézeti képen cysticus úrök azonosíthatók. D) A 3/C ábra felnagyítva: középen organoid intestinalis fal struktúrával rendelkező praepubertalis típusú teratoma figyelhető meg

borvizsgálatok során AFP- és béta-hCG-szintet kontrolláltunk. Az első kontrollvizsgálaton az AFP az előző értékhez képest csökkent. Az öt hónapos kontrollvizsgálaton már mindkét érték a normáltartományban volt mérhető.

\section{Megbeszélés}

Négy év során 4 csecsemőnél észleltük egyéves kor alatt a here cysticus elváltozásait. Az angol irodalom felveti egyes esetekben az elváltozás congenitalis eredetét a ko- rai észlelés miatt $[5,7]$, ezt a mi tapasztalataink is támogatják (lásd első beteg). Az oldaliság tekintetében az irodalom jobb oldali dominanciáról számol be $[1,7]$.

A here cysticus elváltozásai csecsemókorban egy spektrumot fednek le, a kórszövettani vizsgálatok során számos különböző entitás igazolható. Ahogy az 1. táblázatban látható, az általunk észlelt 4 csecsemőben az első vizsgálat során hasonlónak tûnő laesiókat találtunk, de végül különböző diagnózisok születtek. A here praepubertalis cysticus elváltozásai döntően jóindulatúak [4]. Az egyszerú cysták és a praepubertalis teratomák is jóindulatúak, malignizálódásra nem hajlamosak.

1. táblázat | Betegeink klinikai adatainak összefoglalása

\begin{tabular}{lllll}
\hline & Első beteg & Második beteg & Harmadik beteg & Negyedik beteg \\
\hline Elsó észlelés & Születéskor & 5 hónapos korban & 4 hónapos korban & 6 hónapos korban \\
\hline Panaszok & Nincsenek & Nincsenek & Nincsenek & Nincsenek \\
\hline Oldaliság & Bal & Bal & Jobb & Jobb \\
\hline Képalkotó & UH & UH & UH, MR & UH \\
\hline Diagnózis képalkotóval & Simplex cysta & Simplex cysta & Teratoma & Simplex cysta \\
\hline Makroszkópos lelet & Simplex cysta & Simplex cysta & Simplex cysta & Simplex cysta \\
\hline Mikroszkópos lelet & Testicularis teratoma & Aspecifikus cysta & Epithelialis cysta & Praepubertalis teratoma \\
\hline Mütéti megoldás & Enucleatio & Enucleatio & Orchiectomia & Enucleatio \\
\hline Ellenoldali here & Érintetlen & Érintetlen & Érintetlen & Érintetlen \\
\hline
\end{tabular}

$\mathrm{MR}=$ mágneses rezonancia; $\mathrm{UH}=$ ultrahang 
A betegeinkben végzett UH-vizsgálataink során 3 esetben egyszerú cysta ábrázolódott, körülötte múködó hereszövettel. I esetben szeptált, sürü bennékü cysta volt látható. Emiatt MR-vizsgálat történt, amely teratomát véleményezett. A műtét után végzett kórszövettani vizsgálat ezt az elváltozást is egyszerü cystának találta.

Az UH-vizsgálat elegendő lehet a kezelési terv felállításához, ugyanakkor a pontos diagnózishoz nem mindig elegendő. A multiparametrikus UH-vizsgálat, elasztográfiás módszerrel, talán még megbízhatóbb diagnózissal szolgálna a here elváltozásainak esetében $[8,9]$, de ez a módszer nem áll rendelkezésünkre. Tapasztalataink alapján (lásd harmadik beteg) a magasabb rendû képalkotó vizsgálat (MR) elvégzése sem volt elegendő a pontos diagnózis felállításához, a terápiás tervet viszont nem módosította, csak annak megtervezésében volt segítségünkre. Ezek alapján nem tartjuk szükségesnek magasabb rendü képalkotó bevonását a diagnosztikába. Pontos diagnózis csak kórszövettani vizsgálat után állítható fel.

Egyes szerzők tapasztalatai alapján a here cysticus elváltozásai képesek olyan mértékig növekedni, amíg teljesen elfoglalják a hereparenchyma helyét, így mielőbbi eltávolításuk javasolt [7].

Az irodalmi adatok alapján, feltételezett jóindulatú elváltozás esetében is, a legtöbb esetben inguinalis feltárást követően, a funiculust lefogva történt meg az enucleatio. Erre a potenciális tumorszóródás megelőzésének érdekében került sor [10]. A publikált esetek többségében intraoperatív fagyasztott metszeteket küldtek szövettani vizsgálatra $[4,10]$. A mi betegeink közül 3 csecsemónél, tekintettel a feltételezett jóindulatú elváltozásra, scrotalis feltárást követő enucleatiót végeztünk a funiculus megkímélése és a jobb esztétikai eredmény érdekében.

A mütétek alatt észlelt makroszkópos kép mind a 4 esetben hasonló volt, egyszerú cystának imponáltak az elváltozások. 3 csecsemőben a cysticus elváltozás jól elkülöníthető volt a here szövetétől, a here megkímélésével el lehetett távolítani in toto. 1 betegben az ép hereszövet hiánya miatt orchiectomiát végeztünk.

Simplex cysta esetén először 1988-ban számoltak be a hereszövet megtartásával járó mútétről [2]. A későbbi publikációk ugyancsak hereszövet-megtartó kezelést ajánlanak simplex cysta esetén [1]. Amennyiben a teratoma lehetősége felmerült, az irodalom az 1990-es évekig konzekvensen orchiectomiát javasolt [11-15]. Az 1990es évektől kezdve jelentek meg közlemények a heremegtartó mútétek alkalmazásáról, illetve javaslatáról [3, 4, 10, 16-19].

$\mathrm{Az}$ enucleatio elégséges teratoma esetében is, mivel malignizálódásról, illetve metasztatizáló betegség lehetőségéről ebben az életkorban, praepubertalis teratoma esetén, irodalmi adat alapján sem beszélhetünk $[3,10$, 18]. Mindezek és saját tapasztalataink alapján mi mindenképpen az ép hereszövet megtartását javasoljuk egyszerü cysta és praepubertalis teratoma esetén, amennyiben az technikailag lehetséges. A mütétek utáni nyomon követésről megoszlanak a vélemények. Betegeinknél egyéni mérlegelés alapján zajlott a nyomon követés, melynek során kórosat nem észleltünk. Egy nagyobb esetszámú tanulmány tapasztalatai alapján hosszas nyomon követés során sem észlelték a teratoma kiújulását az azonos vagy az ellenoldali herében, sem áttét kialakulását [4].

Anyagi támogatás: A közlemény megírása és a kapcsolódó kutatómunka anyagi támogatásban nem részesült.

Szerzôi munkamegosztás: B. D. az általa és a további szerzők által észlelt esetek összegzésében, valamint a szakirodalom áttekintését követően a publikáció elkészítésében vett részt. B. E. és G. G. az általuk észlelt esetek ismertetésével és a közlemény revíziójában segédkeztek. M. G. a betegek radiológiai véleményezésében, egyes vizsgálatok elvégzésében vett részt. S. D. a kórszövettani minták elemzésével és véleményezésével járult hozzá a közlemény létrejöttéhez. V. A. az általa észlelt esetek ismertetésével, szakmai tanácsokkal és a publikáció szerkesztésével járult hozzá a közlemény elkészítéséhez. A cikk végleges változatát valamennyi szerző elolvasta és jóváhagyta.

Érdekeltségek: A szerzőknek nincsenek érdekeltségeik.

\section{Irodalom}

[1] Honjo O, Uemura S, Murakami I. Simple testicular cyst in infants: a case report and review of the literature. Eur J Pediatr Surg. 2001; 11: 425-427.

[2] Altadonna V, Snyder HM 3rd, Rosenberg HK, et al. Simple cysts of the testis in children: preoperative diagnosis by ultrasound and excision with testicular preservation. J Urol. 1988; 140: 15051507.

[3] Kay R. Testis tumors in children. In: Belman AB, King LR, Kramer SA. (eds.) Clinical pediatric urology. Fourth edition. CRC Press, Boca Raton, FL, 2002; pp. 1313-1323.

[4] Shukla AR, Woodard C, Carr MC, et al. Experience with testis sparing surgery for testicular teratoma. J Urol. 2004; 171: 161163.

[5] Schmidt SS. Congenital simple cyst of the testis: a hitherto undescribed lesion. J Urol. 1966; 96: 236-238.

[6] Semjén D. Incidence of benign adult teratoma and comparative molecular (FISH) and immunohistochemical study in childhood and adult malignant cases. Doctoral thesis. [A benignus felnőttkori teratoma gyakorisága, valamint összehasonlító molekuláris (FISH) és immunhisztokémiai vizsgálata a gyermekkori és a felnőttkori malignus esetekkel. Doktori értekezés.] Pécsi Tudományegyetem, Általános Orvostudományi Kar, Pathologiai Intézet, Pécs, 2018. [Hungarian]

[7] García CJ, Zúñiga S, Rosenberg H, et al. Simple intratesticular cysts in children: preoperative sonographic diagnosis and histological correlation. Pediatr Radiol. 1999; 29: 851-855.

[8] Reginelli A, D'Andrea A, Clemente A, et al. Does multiparametric US improve diagnostic accuracy in the characterization of small testicular masses? Gland Surg. 2019; 8: S136-S141.

[9] Fang C, Huang DY, Sidhu PS. Elastography of focal testicular lesions: current concepts and utility. Ultrasonography $2019 ; 38$ : 302-310. 
[10] Rushton HG, Belman AB, Sesterhenn I, et al. Testicular sparing sugery for prepubertal teratoma of the testis: a clinical and pathological study. J Urol. 1990; 144: 726-730.

[11] Testicular tumours. In: Dénes J, Pintér A. (eds.) Pediatric surgery and its borderlines. [Heredaganatok. In: Dénes J, Pintér A. (szerk.) Gyermeksebészet és határterületei.] Medicina Könyvkiadó, Budapest, 1987; pp. 391-395. [Hungarian]

[12] Pintér A. Testicular tumours. In: Pintér A. Syllabus of padiatric surgery. [Heretumorok. In: Pintér A. Gyermeksebészeti vezérfonal.] Medicina Könyvkiadó, Budapest, 2005; pp. 184-186. [Hungarian]

[13] Brosman SA. Male genital tract. In: Kelalis PP, King LR, Belman AB. (eds.) Clinical pediatric urology. Second edition. Saunders, Philadelphia, PA, 1985; pp. 1202-1219.

[14] Duffy PG, Sebire NJ. Genitourinary malignancies. In: Thomas DF, Duffy PG, Rickwood AM. (eds.) Essentials of paediatric urology. Second edition. Informa Healthcare, CRC Press, Boca Raton, FL, London, 2008; pp. 295-306.

[15] Straub E, Hohenfellner R. Testicular tumors. In: Eckstein HB, Hohenfellner R, Williams DJ. (eds.) Surgical pediatric urology. Georg Thieme Publishers, Stuttgart, 1977; pp. 466-473.
[16] Ross JH, Kay R, Elder J. Testis sparing surgery for pediatric epidermoid cysts of the testis. J Urol. 1993; 149: 353-356.

[17] Walla JS. Gonadal tumors. In: Stringer MD, Oldham KT, Mouriquand PD. (eds.) Paediatric surgery and urology: long-term outcomes. Second edition. Cambridge University Press, Cambridge, 2006; pp. 707-723.

[18] Pinter A. Testicular tumors. In: Gupta DK, Carachi R. Pediatric oncology (Surgical and medical aspects). Jaypee Brothers Medical Publishers, New Delhi, 2007; pp. 287-298.

[19] Fábián K, Mohay G, Semjén D, et al. Testicular cyst in childhood - a little-known entity. [Herecysta gyermekkorban - egy kevéssé ismert entitás.] Gyermekgyógy. 2017; 68: 117-119. [Hungarian]

(Balogh Dorottya dr., Pécs, József Attila út 7., 7623 e-mail cím: baloghdorottya333@gmail.com)

\section{"Beneficia plura recipit qui scit reddere." (Több jót kap az, ki képes viszonozni.)}

A cikk a Creative Commons Attribution 4.0 International License (https://creativecommons.org/licenses/by/4.0/) feltételei szerint publikált Open Access közlemény, melynek szellemében a cikk bármilyen médiumban szabadon felhasználható, megosztható és újraközölhetö, feltéve, hogy az eredeti szerzỏ és a közlés helye, illetve a CC License linkje és az esetlegesen végrehajtott módositások feltüntetésre kerülnek. (SID_1) 